\title{
TRABALHO E TRABALHADORES NA REGIÃO DO "MAR DE CANA E DO RIO DE ÁLCOOL"
}

\section{Maria Aparecida de Moraes Silva ${ }^{2}$ maria moraes@terra.com.br}

\section{RESUMO:}

Objetiva-se à análise da situação dos trabalhadores, migrantes temporários, empregados nas usinas de cana-de-açúcar e álcool no interior do estado de São Paulo, consideradas as maiores do país.Nas últimas décadas tem-se verificado que o emprego de máquinas e tecnologias avançadas caminham lado a lado com o aumento da exploração e do agravamento das condições de trabalho, caracterizadas por baixos salários, perda dos direitos, casos de escravização por meio de dívidas, sem contar os registros de mortes, ocasionadas pelas altas exigências de produtividade, e usos de drogas estimulantes durante o trabalho. Objetiva-se à análise das correntes invisíveis que contribuem para a superexploração e a escravização existentes. A permanência da mão-de-obra migrante, falsamente denominada temporária, é o suporte do modelo lucrativo do agronegócio das usinas canavieiras paulistas.

Palavras-chave: modernização da agricultura e trabalho; agronegócio e relações de trabalho; trabalho escravo contemporâneo; migração e trabalho.

\begin{abstract}
:
This article analyzes the situations of workers, temporary migrants, employees in the sugar-cane and alcohol industries at rural areas of São Paulo state, considered to be the largest in country. In the last decades it has been verified that the employment of machines and advanced technologies are walking side by side with the increase of exploration and worsening of work conditions, characterized by low wages, loss of rights, cases of enslavement through debts, besides the deaths registrations, caused by discharges of productivity demands, and uses of stimulating drugs during work. This article focuses the analysis of the invisible currents that contribute to the over exploration and enslavement of rural workers. The permanence of migrating labor, falsely denominated temporary, is the support of the agrobusiness lucrative model related to the sugar-cane industries from São Paulo state.
\end{abstract}

\footnotetext{
${ }^{1}$ Texto aceito para a publicação na revista latinoamericana de estudios Del trabajo (RELET), n. 18, 2005.

${ }_{2}$ Professora visitante do PPG/Geografia Humana/USP; Colaboradora do PPG/Geografia/UNESP/PP; Pesquisadora do CNPq. Autora do livro: Errantes do fim do século. EDUNESP, 1999.
} 
Key-words: agriculture modernization and work; agrobusiness and work relations; contemporaneous slave work; migration and work.

No dia 12 de setembro de 2004, o primeiro-ministro japonês, Junichiro Koizumi, sobrevoou os canaviais da Região de Ribeirão Preto/SP ${ }^{1}$, na companhia do Governador do Estado, Geraldo Alckimin, e do Ministro da Agricultura, Roberto Rodrigues. Em entrevista ao Jornal Folha de S. Paulo, o ministro afirmou que a intenção em levar o primeiro-ministro japonês a esta região era para que ele visse que aí existe "um mar de cana" e é produzido "um rio de álcool” todos os dias. Após visitar a usina São Martinho, que produz 2 milhões de litros de álcool diários, as autoridades brasileiras, bem como os usineiros, sentiram-se satisfeitos com as possibilidades de venda deste produto ao Japão, signatário do Protocolo de Kyoto, visando à solução de problemas ambientais e econômicos, graças à incorporação de 3\% de álcool à gasolina, aliás medida já aprovada em lei no Japão, embora não ainda implementada. (Folha de S. Paulo, 15/09/04, Caderno Dinheiro, B12) ${ }^{1}$.

Se por um lado, a paisagem verdejante dos canaviais paulistas impressionou o representante japonês, imprimindo-lhe a imagem de um mar de cana, também presente ao visitar os gigantescos depósitos receptores de verdadeiros rios de álcool da referida usina, por outro lado, as imagens enegrecidas dos trabalhadores rurais pela fuligem da cana queimada, altamente poluente, seguramente não foram captadas pela visão do visitante, nem tampouco pelas palavras do Ministro da Agricultura brasileiro.

Esta notícia, aliás, também veiculada pelos meios televisos de comunicação, me trouxe à lembrança a riqueza dos ensinamentos da Utopia de Tomás Moro, livro escrito no início do século XVI. A imagem retratada numa parte deste livro se refere às pastagens para a criação de ovelhas, cuja lã alimentaria a nascente indústria de tecidos na Inglaterra. $\mathrm{O}$ autor, por meio de um diálogo imaginário, a fim de evitar as perseguições do poder da nobreza e da Igreja Católica, indigna-se diante da situação de um país onde as ovelhas "devoravam" os homens, casas e propriedades rurais, provocando a miséria e a fome de milhares de pessoas que perdiam suas terras e eram obrigadas a migrar para as cidades em busca de subsistência. Na verdade, o que Tomás Moro via estava muito além do verde das pastagens; como arguto observador da sociedade inglesa daquele momento, ele via o invisível. Seu ponto de observação era outro, ou seja, por detrás das pastagens e ovelhas, ele enxergava aqueles que sofriam o 
processo de expropriação, portanto, aqueles que foram obrigados a viver à margem daquela sociedade em benefício da elite privilegiada.

Obviamente, não foi este o ponto de observação daqueles que sobrevoaram os canaviais paulistas, decorridos mais de cinco séculos. A partir da década de 1990, solidifica-se cada vez mais a ideologia do agronegócio no Brasil, que consiste em demonstrar que a aplicabilidade da ciência na agricultura, por meio de tecnologias cada vez mais sofisticadas, por grandes empresas nacionais e internacionais, é o modelo de progresso associado ao desenvolvimento econômico. Esta demonstração ganha força a partir dos dados quantitativos apresentados. Assim, os números acerca do aumento da produção e da produtividade de grãos, tais como soja, café, algodão, cana-de-açúcar, bem como os derivados, álcool, suco de laranja, além de outros produtos são cada vez mais crescentes e contribuem para dinamizar as indústrias que fornecem equipamentos, máquinas e insumos empregados pelas empresas agrícolas, espalhadas por todas as regiões do país. Assim, por exemplo, notícias veiculadas pelos media acerca dos milhões de toneladas de soja, de açúcar, dos bilhões de litros de álcool são o certificado do sucesso deste modelo, algo verificado nas grandes feiras agrícolas - Agrishows realizadas em várias cidades do país, onde são feitos grandes negócios, cujas cifras atingem, como na última feira em Ribeirão Preto, mais de um bilhão de reais! Outro fator que contribui para este sucesso do agronegócio é o desenvolvimento de pesquisas científicas em diversas áreas do conhecimento, realizadas em várias universidades do país e também em empresas estatais como a EMBRAPA, cujo reconhecimento é nacional e internacional. Apenas dois exemplos ilustram esta notoriedade: a pesquisa sobre o genoma da cana e a clonagem de animais. Portanto, pode-se afirmar que este modelo se construiu a partir de redes, envolvendo, o Estado, empresas nacionais e internacionais e universidades ${ }^{2}$.

No que tange ao aspecto político, o agronegócio tem sido o símbolo do desenvolvimento econômico do país, por meio do saldo positivo do comércio exterior, graças ao aumento das exportações, sobretudo de produtos agrícolas, que vêm garantindo, sobretudo nos últimos anos, o pagamento dos juros da dívida externa e permitindo que as taxas do superávit primário sejam aumentadas pelo atual governo. Vale a pena ainda indicar as grandes vitórias logradas pelo Ministério das Relações Exteriores em relação ao comércio de algodão para os Estados Unidos e de açúcar para a União Européia ${ }^{3}$. 
Diante deste panorama, o objetivo neste texto é contribuir para as reflexões referentes às relações e formas de trabalho implantadas por este modelo de agricultura, levando-se em conta não apenas o processo de precarização das relações de trabalho e do desemprego, causado pelo emprego de máquinas, algo que foi desenvolvido em outro momento (SILVA, 2004, p. 29-78), porém aprofundar a discussão sobre os elementos visíveis e invisíveis que caracterizam a complexidade do trabalho, a partir da realidade ora existente. Ressalta-se, de antemão que a pretensão situa-se não numa conceituação prévia, porém na expectativa de que as reflexões seguintes, baseadas em dados empíricos, possam contribuir para o desvelamento dos elementos ideológicos, mascaradores, que estão embutidos nas relações de trabalho nesta agricultura. Segundo a metodologia marxista, apresentada na Introdução de 1857, as relações entre os níveis abstrato e concreto se passam da seguinte forma: o ponto de partida é o teórico, que, por sua vez, tem o concreto como pressuposição ao espírito; o ponto de chegada é o resultado das relações entre o concreto e abstrato. Logo, o ponto de partida não coincide com o ponto de chegada, ou seja, nas palavras de Marx, se o abstrato fosse igual ao concreto não haveria a necessidade da pesquisa. O resultado final é o concreto pensado.A fim de facilitar a exposição, serão feitas algumas considerações sobre as relações de trabalho implantadas por grandes empresas em outras áreas do país, para, em seguida, abordar a situação dos chamados canavieiros, trabalhadores empregados no corte da cana durante os períodos de safra no interior do estado de São Paulo.

\section{LONGE DOS OLHOS}

Nos limites deste texto, serão privilegiadas informações recentes e atuais sobre as formas de trabalho empregadas por grandes empresas que, desde o período da ditadura militar, vêm atuando na agricultura brasileira e empregando formas de trabalho não condizentes com aquelas referentes ao assalariamento e à venda livre da força de trabalho. Além das publicações do Ministério do Trabalho, CPT, Pastoral dos Migrantes, ISA e outros organismos, alguns estudiosos já se debruçaram sobre esta questão (Esterci, 1994, 1999; Martins, 1995; Sutton, 1994; Figueira, 1999; Trabalho escravo no Brasil Contemporâneo, 1999), trazendo contribuições extremamente importantes à compreensão das variadas formas de exploração da força de trabalho, muitas das quais são escravistas, cujas conceituações serão retomadas mais adiante.

Geralmente, os registros de trabalho escravo são feitos em lugares distantes da região sudeste, nas chamadas áreas de fronteira agrícola, portanto, a variável geográfica 
é, com muita freqüência, vista como um dos determinantes da explicação das relações escravistas. $\mathrm{Na}$ realidade, o ponto de observação destes registros incide-se longe daquele considerado o centro dinâmico e moderno do país, ou seja, a região sudeste, especialmente, o interior do estado de São Paulo, atualmente, considerada o coração do agronegócio do país.Se por um lado, tais registros e denúncias são importantes para punir e frear tais práticas, por outro lado, o silêncio ou até mesmo a negação de relações escravistas no centro moderno e dinâmico do agronegócio pode conduzir a possíveis vieses de análise e, pour cause, reforçar a ideologia modernizante que aí se processa. Frisa-se, contudo, que não se pretende negar a importância dos registros, denúncias e punições nas chamadas regiões de fronteira agrícola, muitas vezes interpretadas como os confins, como o atraso, como o símbolo do Brasil arcaico, como o outro (o segundo) Brasil. O objetivo destas reflexões é deslocar o eixo de análise priorizando não os aspectos quantitativos, porém os qualitativos, não os adjetivos que estas formas de trabalho possuem - trabalho escravo, degradante, forçado, em condições subumanas, em condições análogas à de escravo. Objetiva-se compreender este trabalho em sua essência e não apenas em sua aparência, ou seja, pretende-se compreendê-lo enquanto substantivo e não enquanto adjetivo.

Recente publicação do Observatório Social confirma esta tese, demonstrando que o estado do Pará é o mais representativo destas ocorrências, além de Rondônia e Maranhão. As atividades, relativas ao desmatamento e pecuária, segundo esta fonte, são responsáveis por três quartos da incidência de trabalho escravo. Porém, há também ocorrências nas atividades agrícolas, extração de madeira e produção de carvão. Quanto aos números, dados da CPT registram 25 mil, enquanto a Contag aponta para $40 \mathrm{mil}$ trabalhadores escravizados atualmente no país. Entre 1995 e 2003 foram fiscalizadas 1011 fazendas e libertados 10. 726 trabalhadores. Este número passa para 16 mil incluindo o primeiro semestre de 2004. Enfim, graças á mobilização de vários setores da Sociedade Civil, do Estado, da OIT, de Organizações Internacionais, como a ISA (AntiSlavery International), por meio de denúncias, prisões, condenações e projetos de leis específicas - confisco de terras em que for encontrado trabalho escravo, suspensão de crédito aos fazendeiros escravocratas e transferência para a esfera federal dos crimes contra os direitos humanos - a escravidão contemporânea tem sido revelada e combatida. Neste sentido, a criação em 1995, do Grupo Especial de Fiscalização Móvel do Ministério do Trabalho e o Plano Nacional de Erradicação do Trabalho escravo em 2003, pelos governos federais ${ }^{5}$. 
Vale ainda destacar a série de reportagens recentes publicadas pela Folha de S. Paulo, sob o título de Lavoura Arcaica, pelas quais há uma combinação entre empresas modernas que empregam alta tecnologia e o emprego de mão-de-obra escrava.

"A terra do Meio, uma área de floresta densa entre os rios do Xingu e Iriri, no sudoeste do Estado do Pará, é o novo foco de ocorrência de trabalho escravo na região Norte do País. Na quinta-feira passada, 70 trabalhadores foram resgatados por um avião Búfalo da FAB de um local que estava sendo desmatado para os finais de formação de pastagem e criação de gado ${ }^{6}$.

Levantamento exclusivo da Folha com base em 237 relatórios de fiscalizações do Ministério do Trabalho, realizadas entre janeiro de 2000 e dezembro de 2003 revela que o trabalho escravo no Brasil acompanha o avanço das fronteiras agrícolas e da pecuária e está presente em grandes empreendimentos agrícolas para a exportação e em modernas fazendas de criação de gado que estão no topo da vanguarda tecnológica.E a face obscura de parcela do agronegócio, uma cicatriz escondida em meio á riqueza. Para conhecer a realidade do trabalho análogo à de escravo no Brasil, a reportagem da Folha, primeiro, mergulhou nos processos de grupo de fiscalização móvel do Ministério do Trabalho - considerando só os processos com "resgate" de trabalhadores. Em seguida, visitou os municípios de Marabá, Xinguara, Curionóplis e Rendenção, no sul do Pará, considerada uma área endêmica do trabalho escravo ${ }^{7}$.

O ministério do Trabalho retirou 32 rurais de uma das maiores fazendas de criação de gado do país - a Agroprecúaria Roncador, em Barra do Garças, MT - por se encontrarem em situação análoga à de escravo. A propriedade tem 103 mil cabeças de gado ${ }^{8}$.

Como foi dito acima, os registros de trabalho escravo referem-se á fronteira agrícola do país. Este tema foi estudado em profundidade pelo professor José de Souza Martins em vários trabalhos. Sua tese é a de que as relações escravistas não são anomalia, mas se inserem nas necessidades de reprodução ampliada do capital, na ânsia para a obtenção de maiores lucros. A imobilização da força de trabalho, associada à servidão por dívidas, se passa no contexto do que o autor chama de acumulação 
primitiva do capital, característica do processo de formação das fazendas, sobretudo aquelas destinadas às pastagens para a pecuária.

"Essa modalidade de exploração do trabalho se traduz em acumulação primitiva porque é, em parte, produção de capital no interior do processo de reprodução ampliada do capital”. (grifos do autor) (Martins, 1995, p.9). Em suma, a chamada peonagem, sobretudo nos casos recentes, tem produzido os meios de produção a serem utilizados pelo capitalista para a produção de mercadorias, e, não a produção de mercadorias, segundo este autor. Segundo suas fontes, $72 \%$ dos peões são empregados no desmatamento da floresta amazônica para a posterior formação das pastagens para o gado. No total do país, 53,3\% dos peões escravizados foram empregados nessas tarefas e $46,7 \%$ em agricultura e pecuária, indústria extrativa e indústria propriamente dita (p.8).

Não obstante, segundo dados provenientes de pesquisas recentes, além de informações da Pastoral dos Migrantes, sediada em Guariba/SP, da Procuradoria do Trabalho e daqueles publicados pela imprensa, cada vez mais são constantes as denúncias de trabalho escravo nesta região do estado de $\mathrm{S}$. Paulo, dominada pelo agronegócio do açúcar e álcool. Esta situação impõe aos pesquisadores e demais pessoas preocupadas com esta questão, um olhar mais atento, um outro ponto de observação desta realidade social. Não se trata de predefinir as relações deste agronegócio como escravas, nem tampouco caracterizar os registros/denúncias como não escravos. O esforço aqui empreendido é no sentido de, como foi dito acima, analisar a complexidade destas relações, para, em seguida, propor interpretações e definições.

\section{PERTO DOS OLHOS}

No início de 2004, a notícia do assassinato de três fiscais do Ministério do Trabalho, além do motorista, em Unaí/MG foi mais um revelador da face oculta das relações de trabalho no agronegócio, sobretudo porque dentre os suspeitos, encontramse dois grandes plantadores de feijão da região, Antério e Norberto Mânica ${ }^{4}$. Por outro lado, a opinião pública no mês de outubro, novamente se indignou diante de outra notícia, segundo a qual, um dos suspeitos, Antério Mânica, embora preso, havia se candidatado a prefeito desta cidade e vencido as eleições com cerca de $72 \%$ dos votos, e, em seguida, por meio da concessão de habeas corpus, havia sido colocado em liberdade. 
No entanto, além do assassinato dos fiscais do trabalho em Unaí/MG, há outras denúncias de trabalhadores escravizados na região sudeste, nos estados de $\mathrm{S}$. Paulo e Rio de Janeiro, recentemente publicados pela grande imprensa:

O Grupo José Pessoa - produtor de açúcar e álcool - perdeu o direito de uso do Selo Balanço Social/Betinho, por responder a processo judicial análogo a escravo em Campos, no norte fluminense.

Segundo o procurador de Trabalho de Campinas ... o empresário, Cláudio Donizete Rossi Matheus, produtor de tomates, manteve por mais de uma ano, uma família de alagoanos trabalhando em condições subumanas, sem registro em carteira de trabalho e em jornada de trabalho exaustiva. $O$ empresário responde a processo trabalhista - o primeiro da história da $15^{a}$. Região da Procuradoria do trabalho, responsável por 600 cidades, por não ter cumprido o acordo para pagar os direitos à família, que voltou para Arapiraca em $2003^{10}$.

Trabalhadores da cana-de-açúcar trazidos do Piauí foram encontrados em situação degradante em Ituverava: quase 30 pessoas moravam juntas numa casa de cinco cômodos com péssimas condições de higiene, dormiam no chão... não recebiam salários, mas vales para fazer compras no supermercado de José Ruivo, empreiteiro que os aliciou. De acordo com o promotor o caso pode ser enquadrado como redução à condição análoga à de escravo, cuja pena é de reclusão de dois a cinco anos ${ }^{11}$.

O ministério do Trabalho identificou ontem em Conchal/SP pelo menos 300 trabalhadores rurais cortadores de cana vivendo em condições' subumanas'. Eles estavam e alojamentos administrados por agenciadores contratados pela Usina Virgulino Oliveira, cujo sócio-proprietário é o presidente do Conselho de Administração do grupo Copersucar, Hermelino Ruete de Oliveira, um dos integrantes da comitiva do presidente Lula à China no mês passado ${ }^{12}$.

Os dados coligidos pela Pastoral dos migrantes apontam as seguintes ocorrências no ano de 2004: 
Mais de 56\% dos migrantes que chegam no interior de São Paulo para o corte da cana-de-açúcar são aliciados por "gatos" em suas regiões de origem; 31,9\% receberam adiantamento do "gato" para conseguir viajar; 50 trabalhadores provenientes de Cajazeiras (PB) ficaram 8 dias na estrada, passando fome, sede e sono, com o ônibus quebrado, que trazia cortadores de cana para o interior paulista;

No Municipio de Pontal (SP) 30 trabalhadores migrantes dividem uma casa com 4 comodos e somente um banheiro;No Município de Conquista (MG) 40 trabalhadores são explorados pelo "gato" que trouxe do sertão da Paraíba;

No Município de Guariba (SP) 35 trabalhadores rurais foram trabalhar com um gato desconhecido na região de Campinas (SP); eles foram dispensados de uma usina de açúcar da região de Ribeirão Preto (SP) porque não cortavam 12 toneladas de cana por dia;

No Município de Dobrada (SP), mais de 50 trabalhadores rurais vindos de Bom Conselho (PE), foram dispensados da Usina Bonfim em que trabalharam durante um mês e porque não conseguiram atingir a meta de corte de cana de12 toneladas/dia;

A Usina Bonfim da região de Ribeirão Preto (SP) trouxe mais de 250 trabalhadores migrantes da região de Araçuaí (MG) para o corte da cana, porque os trabalhadores locais não atingiram a meta de corte de cana por dia;

Os trabalhadores rurais de um alojamento encravado no meio do canavial da região de Ribeirão Preto (SP), andam até $10 \mathrm{Km}$ a pé para ir a cidade mais próxima comprar pão e biscoitos, porque a comida oferecida pela usina é insuficiente;

Dia 10 de junho/04, saíram de Palmares Paulista (SP), três ônibus de trabalhadores migrantes de volta para a região da Chapada da Diamantina (BA). Eles foram embora porque o que ganhavam cortando cana não era suficiente para comer e ainda ficavam com dividas com o gato.

Três trabalhadores rurais morreram em regiões diferentes do interior de São Paulo, por causa do trabalho estafante.Um em Araçatuba, outro na região de Bauru e o terceiro em Palmares Paulista. O mais velho tinha 
menos de 34 anos de idade e 4 filhos. O trabalhador de Palmares Paulista $(S P)$, em torno de 4 horas da tarde, depois de cortar 120 metros de cana crua começou a sentir cãibras, dores no peito, tremedeiras, suores e em seguida morreu no meio do canavial, deixando mulher e quatro filhos órfãos na Bahia, na cidade de Caturama.

Trabalho escravo: No dia 16/06/2004, ficais do Ministério do Trabalho encontraram varias irregularidade no alojamento de cortadores de cana vindos de Amarante (PI) para trabalhar em Ituverava (SP). A fiscalização ocorreu após denúncias do Sindicato dos Trabalhadores Rurais da cidade de falta de condições de moradia e de exploração dos trabalhadores. As denúncias também foram encaminhadas ao Ministério Público de Ituverava, que vai apurar a suspeita de que os trabalhadores teriam sido submetidos a condições similares à de trabalho escravo.

Durante a operação, os fiscais encontraram péssimas condições de higiene e acomodação nos alojamentos. Em uma casa de cinco cômodos, moram 28 cortadores de cana. Um dos trabalhadores está dormindo desde janeiro sobre dois pedaços de espuma, com os pés para fora.

Os trabalhadores disseram que o empreiteiro que os contratou está descontando água, luz e aluguel nos salários e que nunca chegaram a receber dinheiro. Alem disso, ele estaria obrigando-os a comprar alimentos e produtos de higiene em seu supermercado.

As carteiras de trabalho os cortadores de cana foram contratados por uma empresa em nome de Rita de Cássia Rosa Reque, da cidade de Delta (MG). no entanto, os fiscais puderam constatar que os acertos do salário e os descontos de aluguel, transporte, refeição e despesas são feitos pelo comerciante José Alcides Ruivo, dono do supermercado onde os trabalhadores fazem compras. "Os dados confirmam que o comerciante é mesmo o empreiteiro", disse Roberto Figueiredo, auditor fiscal do Ministério do Trabalho.

No começo da noite, José Ruivo foi localizado e notificado pelos fiscais do Ministério do Trabalho em seu supermercado. Ele não quis comentar as acusações.

Fonte: www.eptv.com.br - Ribeirão 
Trabalho escravo 2: Depois de denúncias, os fiscais do Ministério do Trabalho de Ribeirão Preto(SP), encontraram varias irregularidades nos alojamentos de cortadores de cana vindos do nordeste para os trabalhos temporários em Sertãozinho(SP). Os ficais encontraram péssimas condições de higiene, acomodação e submetidos a condições de trabalho escravo, recebendo valores irrisórios pelo metro quadrado de cana cortada. "O gato trouxe agente pra cá e deixou agente aqui vivendo como um mendigo" enfatizou um trabalhador migrante.

Trabalho escravo 3: Os fiscais do Ministério do Trabalho da Subdelegacia do Trabalho de Franca (SP), estão realizando uma mega operação nas fazendas de café da região. Eles encontraram 52 fazendas com muitas irregularidades, colhedores de café vindos do Vale do Jequitinhonha (MG), trabalhando sem os equipamentos de segurança e alguns até descalços, alojados em condições com total precariedade.

A Polícia Federal recebeu nesta terça-feira( 08/05/04) uma denúncia de trabalho escravo em Piracicaba. O delegado responsável pelo caso, Mário Alexandre Aguiar, explicou que mais de 50 trabalhadores fizeram uma manifestação em frente a um escritório de contabilidade após receberem seus salários.

28/05/2004 - Representantes do Ministério do Trabalho, da Polícia Federal e sindicatos patronal e de trabalhadores se reuniram nesta sexta-feira, em Rio das Pedras (SP), região de Piracicaba, Para discutirem alternativas para acabar com o trabalho escravo em usinas de cana-de-açúcar.

Entre os problemas mais comuns apontados na reunião estão o excesso de trabalho, com jornadas muito acima das 40 horas semanais; os desconto indevidos nos salários, como as faltas por motivos médicos, mesmo com apresentação de atestados e as más condições dos alojamentos dos trabalhadores migrantes.

Para o subdelegado do Trabalho de Piracicaba, Gil Ricardi, apesar dos cortadores serem contratados por empreiteiros, usinas e fornecedores de cana são co-responsáveis pelas condições de trabalho deles. A maioria que 
atua na região de Piracicaba vem de outros estados do Nordeste e Norte de Minas Gerais. Fonte: EPTV Campinas.

A Polícia Federal de Piracicaba indiciou ontem o canavieiro que terceirizou o serviço dos cortadores de cana de Capela (AL). Segundo informações do delegado da PF Mário Alexandre Veloso Aguar, o empresário rural escapou de crime de trabalho análogo ao de escravo, previsto no artigo 149 do Código Penal. Fonte: Jornal de Piracicaba Cidades A-6 quinta-feira, 10 de junho de 2004

A Polícia Federal de Piracicaba vai apurar e existência de crime organizado na contratação de migrantes para o trabalho na safra de canade-açúcar da região. Com base em dossiê elaborado pela Pastoral do Migrante, a PF já destacou agentes para investigar a conexão de varias áreas, no trafico de migrantes. Segundo o dossiê, esses segmentos teriam lucro para intermediar a saída dos safristas de suas cidades de origem, no Norte e Nordeste do país, até municípios como Charqueada, Capivari, Rio das Pedras e Piracicaba (SP).

Os envolvidos no inquérito que investiga suposto trabalho escravo contra grupo de 60 trabalhadores de Quipapá, a 650 quilometros de Recife (PE), podem ser indiciado por crime de formação de quadrilha. $O$ enquadramento terá como base o artigo 288 do Código Penal. Segundo informação da delegado da Polícia Federal em Piracicaba Mário Alexandre Veloso Aguar, a fase de depoimentos deve ser concluida em aproximadamente 20 dias. A PF não vai divulgar nomes dos possíveis indiciados. Fonte: Jornal e Piracicaba Cidades quinta-feira, 27 de maio de 2004 A-9.

A Delegacia Regional do Trabalho de Piracicaba (SP) vai cobrar de canavieiros e usineiros, em reunião marcada para o próximo dia 28 na Câmara de Vereadores de Rio das Pedras (SP), a responsabilidade pela contratação dos cortadores de cana-de-açúcar, na região. Segundo o subdelegado do Trabalho Gil Vicente Ricardi, a intenção é evitar que o serviço se torne precário. E acordo com ele, a maioria dos problemas trabalhistas que envolvem cortadores ocorrem quando o serviço é terceirizado a empreiteiros - conhecidos como "gatos". Fonte: Jornal de Piracicaba domingo, 23 de maio de 2004. 
Delegado Mario Alexandre Veloso Aguar visita alojamento e 62 cortadores de cana-de-açúcar, em Charqueada e enquadra o caso no artigo 149 do Código Penal. "Policia acha indícios do crime que, caracterizado, vale até 8 anos de cadeia”. Fonte: Jornal de Piracicaba Cidades quinta-feira, 13 de maio de 2004.

Debate reuniu representantes dos trabalhadores e usineiros, ontem, na Câmara Municipal.O problema dos trabalhadores que atuam em condições análogas à escravidão no corte de cana foi debatido, ontem, durante encontro na Câmara Municipal de Piracicaba (SP), organizado pela Comissão de Defesa dos Direitos Humanos e Cidadania, presidida pelo vereador Antônio Osvaldo Storel (PT). Fonte: A TRIBUNA Piracicaba, quinta-feira, 12 de agosto de 2004.

A região de Piracicaba é considerada o atual foco do combate ao trabalho escravo pela Polícia Federal, Ministério Público do Trabalho e Ministério do Trabalho, que fará blitze para investigar a ocorrência deste tipo de crime na região de Piracicaba.Em menos de três meses, a Polícia Federal abriu cinco inquéritos, prendeu dois empreiteiros e indiciou nove pessoas envolvidas na prática de suposto trabalho escravo nas lavouras de cana-deaçúcar da região. "Exploração atinge pelo menos 220 trabalhadores rurais". "O procurador considerou a situação de Piracicaba”. "gravíssima”. São (5) inquéritos abertos para investigar o crime, (2) pessoas estão presas, (9) indiciadas e 225 trabalhadores envolvidos, só na região de Piracicaba (SP). Fonte: Jornal de Piracicaba, Cidades, quintafeira, 12 de agosto de 2004.

Durante a mesa-redonda para discussão de ocorrência de suposto trabalho escravo na região de Piracicaba, ontem na Câmara, o procurador do Ministério do Trabalho, Ricardo Garcia, propôs um pacto para o fim da terceirização do corte da cana-de-açúcar e a criação de agenda para debates de temas ligados ao assunto.

O representante da Pastoral do Migrante, Lair Gomes de Oliveira, também propôs a criação de uma comissão com participação de outros segmentos da sociedade civil. Fonte: Jornal de Piracicaba Cidades, quinta-feira, 12 de agosto de 2004. 
Subdelegacia do trabalho de Piracicaba apura denúncia que caracteriza situação de humilhação e desrespeito aos direitos em alojamentos em Charqueada (SP)

“Há falta de registros em carteira, além de salários". Fonte: Jornal de Piracicaba Cidades quarta-feira, 12 de maio de 2004 A-6.

O Ministério do Trabalho denúncia situação de cortadores de cana de Itapira, na região de Campinas (SP). Os trabalhadores migrantes de Cajazeiras (PB) cumprem em uma usina uma jornada superior à permitida por lei. Eles trabalham sete dias e folgam apenas um. A usina será notificada e poderá receber uma multa. Fonte: O Globo Online

Pastoral do Migrante redigiu um manifesto aos podres públicos locais, igrejas, sociedade civil organizada, locatários de imóveis, empresários, fornecedores e intermediários a fim de estabelecer um diálogo sobre a melhoria das condições de trabalho com os usineiros. Mais de 40 migrantes moram em dois alojamentos localizados em uma fazenda da região. Vinte e dois deles estavam em apenas uma casa de seis pequenos cômodos $e$ somente um banheiro.

Cerca de 70 migrantes se espremem em cortiço próximo ao centro da cidade de Palmares Paulista; seis deles vivem em mal cheirosos nove metros quadrados.

A sensação é de estar bem no meio de uma favela do Rio de Janeiro ou São Paulo. Para o visitante, custa acreditar que aquele amontoado de quartos pequenos e sujos fica dentro do perímetro urbano de palmares Paulista (SP). São 70 migrantes da Bahia "empoleirados" no cortiço situado nos fundos de uma casa.

A precariedade de moradias enfrentadas todos os anos pelos migrantes nordestinos na microrregião de Catanduva (SP) chega ao extremo em Santa Adélia. No limite do perímetro urbano, um curral chama a atenção, espremido entre ass casas da cidade. Já não há mais animais. Hoje, o local serve apenas como depósito de ração e para a criação de galinhas. Mas, há dois anos, também havia porcos. ... cinco migrantes moram em um barraco improvisado bem nos fundos do curral...coberto com uma lona preta, de 
caminhão...Foi a situação mais grave que encontramos na região de Catanduva (SP), diz Jadir Ribeiro da Pastoral do Migrante.

O bispo da diocese de Catanduva (SP) e vice-presidente da Conferência Nacional dos Bispos do Brasil (CNBB), Antônio Celso Queiroz, se diz critico das condições de moradia e trabalho dos nordestinos que migram para trabalhar no corte da cana na região, "Esse é um problema que só se resolve com pressão da sociedade”, diz. Em junho deste ano, a Pastoral do Migrante distribuiu uma carta a todas as paróquias da diocese alertando para o problema. O documento teve o aval de dom Celso. O vice-presidente da CNBB prega uma maior responsabilidade das usinas e das próprias administrações dos municípios. "Os proprietários das usinas poderiam ajudar mais, e as prefeituras tinham de fiscalizar melhor. Infelizmente, o empregador pensa que é só pagar o salário do trabalhador e o problema está resolvido. Mas a história é muito mais complicada."

A Subdelegacia do Trabalho de Rio Preto vai se reunir na próxima quartafeira com representantes da Associação dos Produtores de Açúcar, Aguardente e Álcool de Catanduva (SP)-(Apac) para discutir as condições desumanas de moradia a que são submetidos os migrantes nordestinos no corte da cana na região.

"É uma situação critica, totalmente desumana. Vamos propor que as usinas aluguem imóveis melhores e instalem esses trabalhadores com um maior conforto e assistência social permanente”, diz o subdelegado do Trabalho em Rio Preto, Robério Cafagni. Esses locais obedeceriam à portaria 3214 do governo federal, que trata de medicina e segurança no trabalho. Fonte: Diário da Região São José do Rio Preto (SP) Cidades 2B / terça-feira, 24 de agosto de 2004.

Deste do inicio do ano de 2004 a Pastoral do Migrante vem realizando trabalhos sistemáticos juntos aos migrantes temporários. O objetivo é conscientizá-los da sua própria realidade.

Foram 72 alojamentos visitados, que estão encravados no meio dos canaviais, e mais de 4 mil pensões localizadas nas cidades dormitórios, somando mais de 62 mil migrantes, provenientes dos 9 Estados do Nordeste, Norte de Minas Gerais e Norte do Parará. Esse montante de 
migrante está espalhado em 20 dioceses, nas 112 paróquias. Todas visitadas pela Pastoral dos Migrantes da diocese de Jaboticabal (SP) ${ }^{13}$.

Estes dados revelam, como foi dito acima, não somente a precarização das relações de trabalho por meio da superexploração, como também apontam para os seguintes elementos:

As denúncias e registros de condições análogas àquelas de trabalho escravo se reportam aos trabalhadores migrantes, provenientes de várias partes do país, sobretudo aquelas mais pobres. Este fato sugere uma análise que leve em conta a segmentação da força de trabalho, porque na verdade, a separação entre migrantes e não migrantes entre os trabalhadores de fora e os locais encobre a divisão étnica do trabalho, dado que a maioria dos migrantes é constituída por negros e pardos. Isto não significa afirmar que os locais sejam todos brancos; ao contrário. Muitos deles são descendentes de trabalhadores negros, mestiços de diferentes matizes, provenientes destas mesmas regiões, que para cá vieram e se estabeleceram definitivamente a partir das décadas de 1960 e 1970. As chamadas cidades-dormitórios encravadas no meio dos canaviais das usinas tiveram um significativo aumento populacional com a vinda destes migrantes neste período ${ }^{12}$. Não obstante, os critérios de regionalidade - paulista e não paulista são reapropriados pela ideologia étnico/racial que aprofunda as divisões entre os trabalhadores, segmentando-os, segundo a procedência geográfica e escamoteando a variável étnico/racial. Considera-se importante ressaltar estes elementos por duas razões. A primeira delas porque há na maioria dos estudos, o silêncio sobre a etnia destes trabalhadores. A segunda razão se reporta ao fato de que, muito embora a mercadoria vendida seja a força de trabalho e não o trabalhador, a pessoa do trabalhador é constituída por elementos étnicos, de gênero, idade, além dos culturais, que não podem ser vistos de forma separada de sua força de trabalho. Portanto, o valor da força de trabalho é definido não somente pelas necessidades de reprodução física e biológica como também pelas necessidades históricas. São estas necessidades que explicam, desde as primeiras fases da época capitalista, as causas dos deslocamentos de capitais para as regiões mais pobres do mundo, em busca de mão-de-obra mais barata. Considerando o caso brasileiro, a migração de trabalhadores nordestinos - para a Amazônia desde os finais do século XIX, sobretudo a partir da grande seca de 1867, na época da exploração do látex, ou para outras regiões do país, sobretudo para o estado de São Paulo, desde o início do século XX, para as fazendas de café, na condição de 
formadores de fazenda, e, mais tarde para o trabalho nos laranjais, cafezais e nas usinas de cana-de-açúcar, na condição de cortadores de cana -, se constitui como uma constatação histórica da reprodução destes capitais. Assim, desde a gênese do capitalismo na agricultura desta região, os trabalhadores nordestinos e também os mineiros fizeram parte da história de sua classe trabalhadora. Vale ainda lembrar que o caráter temporário do trabalho, sobretudo a partir do surgimento das usinas na década de 1960, na verdade se define pela permanência do temporário, ou seja, trata-se do temporário que se repete indefinidamente.

Vale ainda ressaltar que esta divisão étnico/racial relativa aos migrantes não é uma característica apenas do Brasil. Estudos recentes no México revelam que parte significativa dos trabalhadores migrantes em várias partes do país é constituída de várias etnias indígenas Assim, na região da Baixa Califórnia, praticamente a metade dos trabalhadores era migrante e não falava o espanhol. Estes dados coincidiam com informações oficiais de 1991, para as demais regiões do país. Os idiomas indígenas, especialmente, mixteco, zapoteco e triqui eram falados pela metade dos migrantes. Outras pesquisas revelam ainda que na região do Valle de Culiacán, em 1989, 80\% dos migrantes eram de etnias indígenas. ${ }^{14}$.

Recente estudo da Pastoral dos Migrantes ${ }^{15}$ mostra as correntes migratórias para o interior paulista. Assim, do estado de Minas Gerais partem trabalhadores dos municípios: Araçuaí, Almenara, Januária, Janaúba; da Bahia: Ruy Barbosa, Livramento de Nossa Senhora, Catulé; Alagoas: Palmeira dos Índios; Pernambuco: Garanhums; Mogados da Ingazeira; Paraíba: Cajazeiras; Ceará: Iguatu; Piauí: Campo Maior; Maranhão: Codó e Coroatá. Muitos depoimentos atestam que os migrantes se constituem na maior parte dos trabalhadores empregados no corte da cana. Há usinas, dentre elas, a Bonfim cuja força de trabalho é integralmente constituída por migrantes, sobretudo aqueles provenientes do Vale do Jequitinhonha. Na região de Piracicaba, os migrantes são maioria. Na região de Franca, nas fazendas de café, os números de migrantes mineiros, inclusive mulheres, são também bastante expressivos.

No que tange às condições de moradia dos migrantes, as denúncias apontam não somente para a precariedade como também para as condições subumanas. Na realidade, a precariedade material é um componente da desvalorização econômica, cultural e simbólica destes trabalhadores. É preciso afirmar que esta característica é peculiar à história destes trabalhadores nesta região. Vários depoimentos colhidos ao longo de várias pesquisas revelam que as condições de moradia, com raras exceções, sempre 
foram precárias. Os barracões cobertos com lonas de plástico, casas velhas, utilizadas como depósitos de mercadorias, cheias de ratos, pulgas, baratas, percevejos, cobras, além da péssima qualidade da comida, foram em muitas ocasiões os motivos dos quebra-quebras, dos sinais da recusa e da revolta dos trabalhadores num passado recente $^{16}$.

Quanto às denominadas condições análogas à escravidão, os registros/denúncias se reportam à imobilização da força de trabalho, posta em prática pelos arregimentadores, gatos, os quais são, na verdade, os responsáveis pela chamada terceirização das relações de trabalho, prática esta tão recorrente no mundo atual globalizado, porém que já vem acontecendo há várias décadas nesta agricultura, desde o surgimento do processo de volantização da força de trabalho a partir da década de 1960. A imobilização da força de trabalho corresponde à servidão por dívidas, contraídas com os gatos, desde o momento da partida dos locais de origem. A dívida do trabalhador acaba sendo o elo da corrente que o aprisiona, que o escraviza. Impossibilitado de saldala, em razão dos baixos salários recebidos e da parte destinada aos gatos, o trabalhador é submetido por meio de coações físicas, que, às vezes podem leva-lo à morte, e às coações morais. Os estudos realizados são unânimes em mostrar que o pagamento da dívida é um compromisso moral do trabalhador, ou seja, faz parte das regras e códigos de comportamento dos grupos sociais aos quais pertence. Não sair devendo é o código moral que, paradoxalmente, leva-o a suportar a escravidão (Esterci, 1994, Figueira, 1999, Martins, 1999). As coerções física e moral são também responsáveis pelas fugas. Esta prática de recusa ocorre não somente nas regiões da fronteira agrícola como também faz parte da história dos trabalhadores no estado de São Paulo, desde a época do colonato. A expressão muita conhecida no mundo rural, Anoiteceu e não amanheceu, reflete a sabedoria popular desde os inícios do século XX, sobre a realidade vivida de muitos camaradas nordestinos, colonos imigrantes estrangeiros, empregados nas grandes fazendas de café, que não logravam pagar suas dívidas. Entre os imigrantes japoneses, a palavra yonige referia-se às fugas realizadas à noite, portanto, o mesmo significado do Anoiteceu e não amanheceu.

O resgate destes fatos históricos é importante na medida em que a análise, ao captar o momento passado, lança novas luzes sobre os acontecimentos presentes. Na realidade, não se está diante do novo, do inusitado, porém do velho, de velhas práticas que, todavia não podem ser consideradas arcaicas, nem são apanágios das regiões 
distantes da civilização, porém são partes constitutivas do processo de reprodução destes capitais. Ainda mais. Não são características apenas da realidade brasileira.

$\mathrm{Na}$ Argentina, a atividade de tosa de carneiros na Patagônia e da colheita da erva-mate no extremo nordeste do país são realizadas por migrantes que são arregimentados pelos enganchadores, versão dos gatos brasileiros, nas regiões pobres ou até mesmo nas periferias das cidades. As relações de trabalho também são marcadas pelas dívidas contraídas e pelos baixos salários.

Al acercarse la época de esquila, alrededor de un mes antes de comenzar a esquilar, los contratistas, residentes en su gran mayoría en ciudades de gran y mediana importancia (Trelew, Puerto Madryn, Esquel, Patagones, Río Colorado y Tandil, entre otras), se dirigen a pequeños pueblos o zonas rurales de Chubut y Río Negro principalmente, en busca de "su gente". La regularidad de la relación con el mismo contratista establece un núcleo de trabajadores con los que el contratista "puede contar", y a la vez, para los trabajadores se genera una identificación con algún contratista particular, al que se refieren como "patrón"... Los contratos son verbales y su cumplimiento, desde el momento del reclutamiento hasta la partida hacia la esquila, se basa en una cierta confianza mutua. Los lazos de confianza son una construcción que va más allá de los niveles salariales o ventajas y desventajas calculadas. El trabajo en la esquila es remunerado a destajo y el monto final recibido por el trabajador es en función de la productividad de su trabajo, y no del tiempo trabajado. Tradicionalmente el pago en efectivo es percibido al finalizar la temporada. La relación salarial que temporalmente vincula a los contratistas y los trabajadores por sí sola no da cuenta de los vínculos que los unen, y que se manifiestan en la continuidad de la relación laboral de los trabajadores con un mismo contratista. Los contactos fuera de lo estrictamente laboral fortalecen dicha sujeción ${ }^{17}$.

No tocante à colheita de erva-mate, até a década de 1970, os trabalhadores eram recrutados nos minifúndios em várias regiões da Argentina. A partir da década de 1980, em virtude do processo de expropriação e migração para a periferia das cidades, o recrutamento passou a ser feito nestes locais. Assim, os habitantes das favelas 
(barriadas) passam a fazer parte do exército de reserva das empresas ervateiras, fenômeno este institucionalizado socialmente, conferindo a estas áreas geográficas o atributo de serem espaços físicos onde ofertantes e demandantes de força de trabalho se buscam entre $\mathrm{si}^{18}$.

Um outro dado extraído destes registros/denúncias se reporta à superexploração desta força de trabalho, a ponto de extrapolar os limites físicos, ocasionando as mortes nos canaviais. Somente neste ano de 2004, A Pastoral dos Migrantes registrou três mortes, provocadas pelo excesso de esforço, uma verdadeira overdose do trabalho, denominada birola, pelos trabalhadores. Além das condições alimentares insuficientes causadas pelos baixos salários, do calor excessivo, do elevado consumo de energias, em virtude de ser um trabalho extremamente extenuante -, a imposição da média, ou seja, da quantidade diária de cana cortada, cada vez mais crescente, tem sido o definidor do aumento da produtividade do trabalho, principalmente, a partir da década de 1990, quando as máquinas colhedeiras de cana passaram a ser empregadas em números crescentes. Esta imposição atinge não somente os migrantes como também os trabalhadores locais. Por esta razão, estes capitais necessitam de mão-de-obra jovem, dotada de muitas energias, para o desempenho desta atividade. Assim, a rotatividade torna-se muita alta, em virtude da reposição constante da força de trabalho, consumida durante o processo produtivo.

Em síntese, do conjunto de registros/denúncias acima descrito, três foram as questões levantadas pela presente análise: a segmentação da força de trabalho, a partir da divisão étnica do trabalho, sem contar a questão de gênero, pois as mulheres foram praticamente alijadas do corte da cana ${ }^{19}$; a imobilização da força de trabalho de migrantes, muitos dos quais sujeitados aos gatos em virtude das dívidas contraídas e alojados em condições extremamente precárias; a superexploração, responsável por algumas mortes durante o processo de trabalho. Vale ainda lembrar que, ademais dos casos relatados, o estudo de Cassiano Rumin (2003) na região de Assis constatou a ocorrência da birola e, em outras pesquisas (SILVA, 2004) também houve depoimentos sobre mortes de parentes, atestadas como enfarte pelos médicos, ocorridas após muitas cãibras durante o corte da cana, geralmente, no período da tarde. Levanta-se aqui a hipótese de que o número de mortes deve ser maior do que os conhecidos.

Com o intuito de aprofundar as reflexões sobre a definição ou a conceituação deste trabalho e responder aos questionamentos que estes dados suscitam, optou-se por acrescentar à análise algumas considerações sobre as correntes invisiveis que atam os 
trabalhadores a estas relações caracterizadas pela injustiça social e que causam indignação moral a todos aqueles preocupados com a defesa dos direitos humanos e a construção de uma sociedade mais igualitária.

\section{FUI SER ESCRAVO, PARA NÃO DEIXAR MINHA MÃE MORRER DE FOME.}

Esta frase foi ouvida pela autora ao inquirir João Maria, trabalhador do Vale do Jequitinhonha, em 1988, sobre o conhecimento prévio de ser escravizado na usina em Rio Brilhante $/ \mathrm{MS}^{20}$. A resposta foi afirmativa, seguida desta frase. Depois, permaneceu em silêncio por um longo momento.

No seu clássico livro, Injustiça, as bases sociais da obediência e da revolta, Barrington Moore Jr. (1987) procura respostas às questões relativas à dor e ao sofrimento. Por que, em diferentes épocas e lugares, as pessoas suportam a dor e o sofrimento? Sua tese é demonstrada a partir de três exemplos: o ascetismo, os intocáveis, os párias do sistema de castas da Índia e os prisioneiros do campo de concentração nazista durante a $2^{\mathrm{a}}$. Guerra Mundial. Os ascetas, segundo este autor, escolhem deliberadamente a dor e o sofrimento, sobretudo o físico; muitos dos intocáveis da Índia pareciam demonstrar orgulho de sua condição servil, já que a dor e o sofrimento eram lhes imposto pelo destino social, pela estrutura de castas. Quanto aos prisioneiros dos campos de concentração, a dor e o sofrimento eram lhes imposto pela violência e pela força, embora muitos deles identificavam-se com seus torturadores. Uma linha comum relaciona estes exemplos; o sofrimento e a submissão aparecem a essas pessoas com uma aura tão poderosa de autoridade moral que eles sentem orgulho e prazer em sua dor (p.82). A preocupação do autor é entender os fatores sociais e culturais que criam tais sentimentos, e não propriamente os psicológicos.

Após analisar os três casos diferentes, ele aponta os seguintes fatores sociais e culturais que são comuns a eles: O primeiro se refere à quebra de solidariedade grupal, principalmente em virtude daqueles que se revoltam; isto se dá em virtude de qualquer ato de desafio pode resultar em retaliações contra o coletivo. O segundo processo diz respeito á destruição dos hábitos e vínculos sociais anteriores, o que solapa as bases sociais dos indivíduos. O terceiro fator é definido pelas inúmeras formas de cooptação postas em prática nas situações de dominação. O último processo envolve a fragmentação social no interior do próprio grupo. As divisões sociais - étnicas, classistas, religiosas etc - impostas impedem a cooperação social entre os dominados. 
Estes quatro processos atuam conjunta ou separadamente para criar o sentido de que a dor e o sofrimento são acompanhados de autoridade moral. Ressalta também que essa capacidade do homem para ignorar e suportar o sofrimento é essencial par a sua sobrevivência (p. 132)

Dando prosseguimento a estas considerações, o referido autor apresenta a discussão sobre a recusa do sofrimento e da opressão também nos processos sócioculturais. A mudança é operada quando há o solapamento do sistema de crenças vigente, que confere legitimidade ou naturalidade à ordem social. Assim na área da estrutura social, o aparecimento dos movimentos sociais representa a constituição de uma nova identidade política. Este fato provoca, no nível psicológico, a infusão de energia na alma humana que lhe dá o poder de julgar e agir (p.124). No que tange ao solapamento do processo cultural ele é feito mediante a destruição da justificação do estrato dominante (p. 127).

À luz destas reflexões, acredita-se que há elementos para interpretar a resposta dada por João Maria à situação de escravidão experimentada para não deixar a mãe morrer de fome e também ao silêncio, ao indizível que se seguiu àquele momento. Segundo o que foi visto em linhas atrás, os migrantes são originários de áreas pobres do país. Com base nos estudos de Esterci (1994), os peões são camponeses, pequenos agricultores que deixam suas terras em busca de trabalho assalariado para complementar a renda familiar ou ainda para a satisfação de outras necessidades, sobretudo quando são jovens, para a aquisição de mercadorias capitalistas (rádios, óculos, roupas, tênis etc.). Esta situação também foi encontrada em outra pesquisa realizada com migrantes do Vale do Jequitinhonha (Silva, 1988; Silva, 1999; SILVA, 2001). Na maioria das vezes, se trata de homens jovens, casados ou solteiros ${ }^{21}$. Mas, a satisfação de todas estas necessidades está assentada em elementos simbólicos. A migração temporária aparece como uma estratégia, como uma solução material num duplo sentido: por um lado, o assalariamento permite a compra de alimentos, garantindo, assim, um patamar mínimo de sobrevivência; por outro, a saída da terra corresponde à volta, já que o trabalho assalariado é temporário. Cria-se, portanto um elo de complementaridade bastante estreito entre estas realidades, que, apesar de opostas, se servem mutuamente. Em outros termos, a economia capitalista avançada necessita desta mão-de-obra barata em seu espaço por algum tempo, e a economia miserável necessita do parco dinheiro, auferido por alguns de seus membros para continuar existindo. Defende-se aqui, a tese de Rosa Luxemburgo, para quem, o modo de produção capitalista necessita da força de trabalho 
de outras regiões externas ao seu meio para garantir a reprodução ampliada, e, portanto a acumulação.

Um outro ponto a respeito da permanência na terra é a concepção que se tem da terra. Ela não é vista apenas como fator de produção, como preço de mercado, como valor de troca. Ela é muito mais do que isso. "A terra carrega sempre outras conotações - de status, segurança, direitos - mais profundas do que o simples valor da colheita”. (Thompson, 1987, pg. 64). Portanto, a estratégia, a solução material visa também a recomposição do modelo cultural.

A terra aparece muito mais como imagem, amálgama de sonhos, realidade e irrealidade. A terra do outro, a terra que não é da gente é representada como trecho, tempo e espaço de passagem. Em geral, muitas das agruras vivenciadas no trecho não são relatadas nas cartas, elas são silenciadas. Este silêncio existe como um fermento para a produção de outras experiências das gerações futuras. A imagem de São Paulo é quase sempre positivada em nível das representações, tal como aparece nos inúmeros depoimentos:

"Se precisar de alguma roupa, pagar ao armazém, tem que ir pra São Paulo".

"Foi São Paulo que deu roupa pra nós. Antes nós não comprava roupa porque não tinha dinheiro".

São Paulo é que deu pão para os meus filhos. Se não fosse São Paulo, nós tínhamos morrido tudo".

"Este povo só tem dente porque foi colocado em São Paulo”.

"O jeito é a gente queimar o chão. Foi dinheiro de São Paulo que permitiu fazer as casas. Antes, as pessoas morriam e precisavam fazer um buraco na parede pra poder espichar as pessoas, porque os cômodos eram muito pequenos, não dava pra espichar”.

"São Paulo é o pai do Vale do Jequitinhonha".

Em todas estas representações, observa-se uma espécie de transmutação das experiências vividas. Na visão de Antônio T. Montenegro, a experiência é algo que vai além do vivido, o narrador não descreve meramente o acontecido, ele, na verdade, vai além, isto é, ele interpreta o vivido, segundo um conjunto de elementos (re)significados. Talvez resida aí, a natureza da afirmação dos meninos, quando inquiridos sobre seus 
projetos de vida, ao se referirem à necessidade de irem para São Paulo, "quando inteirarem idade". Portanto, não se trata apenas de discurso, porém de atividade humana, de realização, de práxis. A práxis e o pensamento aparecem numa relação de indissolubilidade $\mathrm{O}$ conteúdo de todas estas narrativas remetem ao imaginário, à recriação da experiência, ao recontar da história e da memória, à (re) invenção de representações simbólicas (Feldman-Bianco;Huse, s.d.).

O fragmento de um depoimento revela a complementaridade e a ruptura existentes entre os dois lugares, o lugar da gente e o lugar que não é da gente:

"É assim. A terra, quando é fraca, a gente tem que sair, ir para São Paulo. Lá a gente trabalha no que é dos outros. Aí, a gente tem o dinheiro. Com o dinheiro que vem da nossa força, a gente manda para a família. Aí, este dinheiro dá a força para a família porque ela pode comprar o alimento. Aí, a mulher fica com a força para poder trabalhar e cuidar da terra, para poder plantar. Por que se não for assim, a mulher não planta, e, aí, a gente não tem colheita".

A força se constitui, na verdade, na metáfora, que é o tropo linguístico dominante desta narrativa. A ruptura está presente na existência do assalariamento, do dinheiro auferido na terra dos outros, em São Paulo. A complementaridade é intrínseca à força do homem que parte e da mulher que fica. Por outro lado, a idéia de força está intimamente associada à força da terra e das pessoas para trabalharem a terra dos outros. A saída está ligada à fraqueza da terra. A forma de compensar esta fraqueza é trabalhar na terra dos outros, mas com a própria força, força que foi produzida pela própria terra. Há, aí, um movimento circular, unindo duas terras separadas no tempo e no espaço. O homem na terra dos outros tem a força para trabalhar. Com o dinheiro produzido por esta força, o homem alimenta a família, que, então passa a produzir a força para trabalhar na própria terra. Somente, assim, pode-se reproduzir a unidade anterior entre homem-terra. Da interação homem-terra, espera-se o produto, a colheita para produzir a força até o mês de maio, quando, novamente, impõe-se a partida para reproduzir a situação anterior.

Estes depoimentos fornecem subsídios importantes à compreensão do processo migratório e também da aceitação das formas de opressão e exploração impostas. Ao longo da vida, os indivíduos vão internalizando estas condutas e padrões de 
comportamento. A análise do conteúdo das cartas dos migrantes revela que as situações de dor e sofrimento são, na maioria das vezes, silenciadas, ou até mesmo negadas. É preciso não esquecer que o migrante parte em busca de melhoria de vida, isto é, de um projeto de ascensão social. O retorno, ou melhor, a representação do retorno é carregada destes valores. Logo, os fracassos, as perdas representariam a ruptura com o ideal da partida, o que pode resultar em sanções negativas por pare do grupo. Esta poderia ser a explicação para as ações daqueles que não retornam, que desaparecem. A pesquisadora, Maria Stela Lemos Borges (2002) recolheu muitos depoimentos de peões em Mato Grosso do Sul, alguns dos quais, na mendicância, que não voltaram ao convívio familiar e grupal, temendo as sanções negativas. $\mathrm{O}$ desgarramento familiar pode conduzir ao desenraizamento social e cultural, cujo processo de alienação é reforçado pelo uso de bebidas alcoólicas que apressa a morte física e social.

Há também que se considerar a situação dos camponeses que perderam suas terras e estão nas periferias das cidades. Esta parece ser a tendência atual, sobretudo a partir da expansão vertiginosa da plantação de soja nos cerrados. Segundo o levantamento feito pela CEPET (Comissão Estadual de Prevenção e Combate ao Trabalho Escravo) no Piauí, a maioria dos trabalhadores recrutados para o trabalho em várias regiões do país já não está mais no campo. Portanto, a migração não visa mais a complementar a renda familiar, mas à sobrevivência do grupo familiar, o que corresponde ao aumento da vulnerabilidade destes trabalhadores no tocante à incorporação das normas de sujeição (Novaes, 2004).

Outro ponto que decorre destas reflexões é o referente aos padrões de masculinidade, ou seja, aos papéis que devem ser desempenhados pelos homens. A figura do chefe de família, do provedor, está associada aos padrões patriarcais, que atravessam todas as classes sociais. Tais padrões, se por um lado, eles conferem poder aos homens, legitimando a dominação masculina sobre as mulheres, por outro lado, eles podem ser considerados como verdadeiros fardos. Deste modo, o homem é identificado como viril, destemido, capaz de enfrentar todos os perigos. Este mais um dos elos destas amarras invisíveis que prendem muitos trabalhadores às redes de trabalho escravo. Não se trata de desconhecimento da realidade a ser vivida. Ao contrário. Trata-se de um verdadeiro enfrentamento, de uma provação para o próprio indivíduo e para o grupo ao qual pertence. É uma espécie de rito de passagem. É assim que se interpreta a frase emitida por João Maria. Ao migrar em busca de salário para evitar a morte da mãe pela fome, ele cumpre o papel viril de destemor e também o do filho provedor, já que o pai 
havia morrido havia vários anos. Assim, sua inserção no grupo é sancionada positivamente. O sofrimento e a dor são silenciados em virtude da internalização de tais valores e padrões sócio-culturais. Esta realidade também pode ser interpretada à luz dos ensinamentos de Elias (1990), sociólogo alemão, segundo os quais, o denominado processo civilizatório ocorre por meio da autodisciplina. Ou seja, a internalização dos valores e padrões de comportamento vão, ao longo da vida, moldando a personalidade dos indivíduos, de tal forma que mesmo a violência passa a ser internalizada, como algo natural. Opera-se, portanto, o processo de naturalização das relações sociais. Deste modo, partir, aceitar a dor e o sofrimento, são os condicionantes deste processo de naturalização, algo que vai sendo transmitido de geração a geração. Mais adiante serão retomadas estas reflexões.

\section{A LIBERTAÇÃO QUE NÃO LIBERTA}

Segundo informações recentes, cerca de um terço dos trabalhadores libertados de situações de cativeiro nas grandes fazendas retorna voluntariamente ao trabalho escravo $^{22}$. Por outro lado, no que tange à situação dos trabalhadores nas usinas e fazendas paulistas, além das dos registros/denúncias de relações escravistas com imobilização dos trabalhadores migrantes e sujeição por dívida, há que se considerar as exigências em torno da alta taxa de produtividade. No que tange à colheita da cana, durante a década de 1980, a média exigida era em torno de cinco a seis toneladas diárias; estes números passam para 10, durante os anos de 1990 e atualmente estão em torno de 12 a 15 . No tocante à colheita de laranja, hoje, a média é de 70 caixas diárias. Em outros anos, nesta atividade, não havia a imposição da média. Ademais deste fator, é preciso não se esquecer que o trabalho nestas duas atividades é por produção, logo, o aumento da produtividade é incorporado pelo próprio trabalhador durante o ato produtivo, o que eleva a taxa de exploração, sem a necessidade de investimentos de capitais em máquinas ou outros equipamentos. Vale a pena ainda afirmar que, segundo o contrato de trabalho estipulado, o não cumprimento da média corresponde ao desligamento do trabalhador no final da semana ou do mês e sua substituição imediata por outro, algo que ocorre com muita freqüência, pois o exército de reserva, sobretudo aquele proveniente das regiões pobres do país, fornece naturalmente a mão-de-obra necessária a estes capitais durante todo o ano.

No que tange ao contrato de trabalho, há dois aspectos a serem considerados. Um deles é a relação jurídica estabelecida entre compradores e vendedores da força de 
trabalho. Neste momento, os dois agentes são portadores de direitos iguais, legalmente reconhecidos, uma vez que a operação envolve um ato de compra e venda feita entre indivíduos livres, isto é, nenhuma corrente visível obriga, pelo uso da força física, a assinatura do contrato, aliás, algo também legitimado pelos representantes dos trabalhadores no momento dos dissídios coletivos. O outro aspecto, menos visível, porém não menos importante, é a aceitação forçada, involuntária, latente deste contrato jurídico.

Segundo Amartya Sen ${ }^{23}$, economista que recebeu o Prêmio Nobel em 1998, há uma relação estreita entre economia, ética, liberdade individual e desenvolvimento. Para ele, o desenvolvimento pode ser visto como um processo de expansão das liberdades reais que as pessoas desfrutam. A liberdade depende dos meios sociais e econômicos (por exemplo, os serviços de educação e saúde) e dos direitos civis (por exemplo, a liberdade de participar de discussões). Portanto, não basta que a liberdade, base das democracias modernas, seja assegurada na Constituição. A história dos diferentes países, sobretudo, aqueles situados na periferia do sistema capitalista globalizado, a liberdade é letra morta. Por outro lado, o desenvolvimento não se mede apenas pelo crescimento do PIB. "O desenvolvimento consiste na eliminação de privações de liberdade que limitam as escolhas e as oportunidades das pessoas de exercer ponderadamente sua condição de agentes”. A liberdade é o principal objetivo do desenvolvimento.

Ainda, segundo este autor, a liberdade somente existe diante de alternativas (no plural), ou seja, de oportunidades, de disposições, de meios para que eles possam escolher a forma que eles almejam para levar adiante seus projetos de vida. Portanto, se não existem alternativas, mas um único caminho, não há liberdade, logo, não há desenvolvimento. Como exemplo, uma criança favelada que não possui oportunidades de freqüentar escola, de ter assistência médica, de se alimentar ou morar dignamente, fatalmente, ela não possui alternativas para se livrar do tráfico de drogas, que se lhe é oferecido como único caminho de vida. Um outro ensinamento importante de Amartya Sen é que as alternativas não se resumem à coisas materiais, portanto, não basta a satisfação das necessidades básicas, como alimentar-se, vestir, ou seja, não bastam a cesta básica, os famigerados, bolsa escola, bolsa família, fome-zero que, muitas vezes, funcionam como meros paliativos para aplacar a fome fisiológica. Existem outras formas de fome. A fome cultural, educacional, social. Não basta ter algumas mercadorias como aparelhos de televisão e rádio. A questão central é a qualidade de 
vida que as pessoas podem levar. É, segundo suas palavras, levar a vida sem sentir vergonha, sentir desejos, poder visitar e cultivar amigos, passear com a família num parque.

Neste momento, vale a pena refletir sobre uma possível escolha de não aceitação do contrato de trabalho por parte dos trabalhadores. No tocante aos migrantes, que já chegam, em sua maioria, endividados, eles não teriam condições financeiras de regressar aos seus lugares de origem, distantes a milhares de $\mathrm{km}$. Além disso, o regresso sem dinheiro para o sustento da família significa, antes de tudo, a violação das normas de comportamento vigentes no interior do grupo ao qual pertence. Portanto, é difícil afirmar que há liberdade no momento da aceitação do contrato de trabalho. É difícil não pensar na vergonha do provedor fracassado. Inúmeros são os casos de trabalhadores desaparecidos. Não somente aqueles que foram assassinados por capangas, segundo as denúncias de muitos estudiosos e agentes de movimentos sociais, dentre eles a CPT. Dentre os desaparecidos, há que se considerar aqueles que fogem e não voltam ao lugar de origem. E mais. Estas fugas também se reportam aos trabalhadores locais, aqueles que são despedidos, que são desempregados em virtude do aumento do emprego de máquinas. Durante as pesquisas em várias cidades dormitórios desta região, foi constatado que, em torno de $30 \%$ das famílias, se referem às chefias de mulheres. Segundo elas, os homens foram embora. Na realidade, não se trata de partida, mas de fuga. Fuga por medo das sanções sociais negativas ${ }^{24}$.

Em ambos os casos, pode-se afirmar, seguindo as idéias de Elias, que há uma pressão constante e regular que é exercida sobre a vida destes indivíduos, os quais mal a sentem porque já se habituaram a ela, porque o comportamento e a plasmação das pulsões foram, desde a infância, ajustados a esta organização da sociedade. A verdadeira coação é aquela que o indivíduo exerce sobre si mesmo, segundo este autor $^{25}$. Logo, a imposição das altas taxas de produtividade do trabalho, que extrapolam os limites físicos dos trabalhadores, levando-os, em alguns casos, à morte ${ }^{26}$, é suportada em virtude deste processo de introjeção da autodisciplina que os acompanha durante toda a vida. Do mesmo modo, pode-se interpretar a reposição energética, por meio da distribuição do leite de soja ou até mesmo da aplicação de injeções - as amarelinhas, segundo a definição dos próprios trabalhadores - a fim de minorar os efeitos de cãibras, provocadas pela perda excessiva de potássio durante a atividade do corte da cana. Em se tratando dos colhedores de laranja, a fim de evitar a contaminação dos pomares, os trabalhadores são literalmente pulverizados com venenos antes do início das atividades. 
Muitos depoimentos foram recolhidos acerca desta prática, normalmente negada pelos proprietários e até mesmo pelos colhedores, em virtude do medo de serem despedidos. Ademais, a colheita da laranja é feita após a aplicação do veneno, o que faz com que os trabalhadores fiquem em contato direto com o produto, o que lhes causa inapetência, alergias, coceiras, feridas e, em alguns casos, desmaios.

Além das mortes ocorridas nos canaviais, há aquelas não registradas, e que ocorrem ao longo de um tempo determinado. Doenças como câncer, provocado pelo uso de veneno, fuligem da cana, além de doenças respiratórias, alérgicas, da coluna, aliadas a quase total impossibilidade de serem tratadas em razão da inexistência de recursos financeiros para a compra de remédios, conduzem à morte física ou social de muitos trabalhadores, cuja depredação de suas forças impede-os de continuar no mercado de trabalho. Recente pesquisa, desenvolvida pela autora deste texto em várias cidades da região de Ribeirão Preto, revelou a existência de homens e mulheres, ainda na idade produtiva, com problemas graves de coluna, doenças de pele e outras, constituindo-se em verdadeiros descartados do mercado de trabalho. A maioria deles não havia conseguido a aposentadoria e sobreviviam graças ao apoio dos vizinhos, parentes e Igrejas locais.

A discussão levada a cabo até agora se constitui num esforço para o levantamento de todos os condicionantes destas relações de trabalho e o entendimento de sua complexidade. Por outro lado, o trabalho, considerado em sua essência constituise em parte integrante do homem, enquanto ser social. Em outros termos, o trabalho é o definidor da essência humana. Por meio do trabalho, historicamente, o homem modificou a natureza e modificou-se a si mesmo. Esta modificação se refere ao próprio ser, à interioridade e não somente às condições exteriores, objetivas e materiais. $\mathrm{O}$ não trabalho significa a negatividade desta essência, portanto a negatividade do próprio ser social $^{28}$. Portanto, o trabalho não traz apenas a satisfação das necessidades físicas e biológicas, como também sociais e ontológicas. A ausência do trabalho corresponderia à ruptura desta base ontológica do ser social que é o trabalho. Este ponto exige, para seu aprofundamento, um tempo maior para a análise. Nos limites deste texto, a menção, ainda que rápida, a esta dimensão do trabalho a partir do pensamento de Lukács é importante para a compreensão das razões da existência das formas visíveis e invisíveis de exploração da força de trabalho, postas em prática pelo capital nesta agricultura.

A elevação continuada da média induz ao sofrimento, dor, doenças e até mesmo à morte. Acredita-se que este fato seja um dos principais pontos de reflexão. Há ainda, 
segundo a pesquisa de Andrade (2003), registros do uso de drogas, como maconha e crack, para o aumento da capacidade de trabalho durante o corte da cana. A frase, Não dá para acompanhar o campo de cara limpa, reflete a crueza e a brutalidade destas relações de trabalho. A maconha, segundo depoimento de um trabalhador, alivia as dores nos braços, já que para o corte de 10 toneladas de cana, são necessários quase 10 mil golpes de facão. Quanto ao crack, trata-se de uma droga estimulante, portanto, o seu uso possibilita maiores ganhos de produtividade. Este fato, além de invisível, é proibido, pois, numa sociedade permeada pela violência como a brasileira, o silêncio, muitas vezes, é uma estratégia de sobrevivência.

$\underline{\text { O aumento da taxa de exploração põe em risco não somente a força de trabalho, }}$ como também o próprio trabalhador. Situação semelhante foi encontrada por Marx, ao analisar o exemplo histórico do capitalismo inglês no início do século XIX. Naquele momento, muitos operários, inclusive mulheres e crianças, morreram em função das extensas jornadas de trabalho. Este fato resultou na intervenção do Estado inglês, por meio da criação de leis reguladoras dos limites da jornada de trabalho, cuja fiscalização coube aos denominados fiscais de fábrica, que representavam o poder do estado.

Desta sorte, a imposição da média, bem como a aceitação pelos trabalhadores, se constitui num dos elos das correntes invisíveis que os atam a estas relações. No que tange aos casos de reincidentes de trabalho escravo, o retorno à mesma situação ocorre em virtude da ausência de alternativas, portanto de liberdade, segundo as palavras de Amatya Sen. O conteúdo latente das duas relações é o mesmo. O elemento mascarador é justamente o conteúdo manifesto, pelo qual há visibilidade nas relações escravistas, em função da imobilização da força de trabalho e da coerção física ou moral. No que concerne aos trabalhadores assalariados e membros do contrato jurídico, estes fatores são camuflados pelas relações livres de compra e venda da força de trabalho.

Das reflexões acima, pode-se concluir que a solução para a morte nos canaviais paulistas, para a depredação dos trabalhadores e para os casos de imobilização e coerção física ou moral, não reside apenas na denúncia ou na definição deste trabalho como degradante, forçado ou até mesmo em condições análogas àquela do escravo. É preciso ir além dos adjetivos. A questão é substantiva. A solução somente poderá advir com a eliminação das causas e não dos efeitos. . O conjunto destas discussões visou ao desvelamento dos elementos ideológicos, portanto mascaradores, que estão embutidos nestas relações de trabalho, consideradas livres. 
A definição de trabalho escravo leva em conta, como já foi dito acima, a imobilização da força de trabalho, a coerção física ou moral. Propõe-se para a reflexão que esta definição passe incorporar as peias invisíveis que imobilizam a força de trabalho, como o contrato, cuja desobediência, além da demissão, poderá implicar na impossibilidade de trabalho futuro, e a imposição da média, que, na realidade é uma coerção moral. Contrato e média são os correspondentes da dívida que escraviza. Eles são a reinvenção moderna de exploração do trabalho do agronegócio paulista.

\section{EM BUSCA DE UMA POSSÍVEL LIBERTAÇÃO QUE LIBERTA}

Retomando as observações feitas acerca das imagens do mar de cana e do rio de álcool mostradas ao ministro japonês, o caminho percorrido neste texto foi o tentar revelar o que não foi mostrado, o não visível, o ocultado, o mundo do trabalho de milhares de homens e também mulheres, anônimos, pobres, não brancos em sua maioria, muitos dos quais originários dos chamados confins deste imenso país. $\mathrm{O}$ interior paulista considerado uma das regiões mais ricas somente o é graças à pobreza vigente nestes confins. Os ensinamentos de Rosa Luxemburgo são necessários à compreensão desta situação. Segundo esta pensadora, a reprodução ampliada do capital somente pode ocorrer em virtude da exploração da força de trabalho proveniente de regiões pobres. Pobreza e riqueza constituem-se assim, duas faces da mesma moeda. As evidências históricas demonstram que as migrações de pobres dos confins acompanham a história dos capitais aplicados nesta agricultura desde sua gênese no início do século XX.

Todavia, a compreensão das relações de trabalho exigiu que a análise levasse em conta não somente as estruturas objetivas como também as subjetivas. Procurou-se um outro ponto de observação analítico, mediante a ótica dos indivíduos/sujeitos historicamente determinados por estas estruturas. Com o intuito de contribuir com as reflexões dos participantes deste evento em torno de uma práxis, que vise à transformação desta realidade social, propõem-se os seguintes pontos para discussão:

Em virtude da segmentação do mercado de trabalho, dividido entre migrantes e não migrantes, cuja permanência ao longo do tempo tem trazido enormes benefícios a estes capitais, e, em contrapartida, enormes prejuízos políticos ao conjunto dos trabalhadores, tanto locais como migrantes, há a necessidade da construção de uma representação política que os une, independentemente da base territorial de suas origens. Se o capital os une num mesmo espaço, e, ao mesmo tempo os separa social e 
politicamente, qualquer estratégia política deverá visar a união destes trabalhadores, possibilitando, assim, a construção do processo da consciência e identidade de classe social. Para isso, torna-se necessário não reproduzir a ideologia dominante mediante a qual os migrantes contribuem para aumentar o desemprego dos trabalhadores locais;

A consecução desta práxis será possibilitada pela construção de uma rede que seja capaz de englobar as representações coletivas dos trabalhadores incluindo os Sindicatos, Feraesp, Pastoral dos Migrantes, Movimentos de Luta pela terra, CPT, Contag, Ministério Público, Ministério do Trabalho, Universidades, enfim todas as representações sociais e políticas que combatem as injustiças sociais.

A construção da rede será um fator extremamente importante para a obrigatoriedade da aplicabilidade do PAS (Fundo de Assistência Social, previsto pela Lei Federal N. 4.870, de dezembro de 1965), que prevê que os municípios onde há plantação de cana e usinas de açúcar e álcool, recebam respectivamente, 1\% do faturamento da cana, $1 \%$ do açúcar e $2 \%$ do álcool. Esta lei, embora em vigor, é letra morta para a contabilidade das empresas.

Nos objetivos da rede deverá constar também a luta pela Reforma Agrária, sobretudo nas áreas de origem dos migrantes. Neste sentido, haveria a diminuição da oferta de mão-de-obra para as empresas, e, conseqüentemente, a imposição de novas relações de trabalho.

\section{NOTAS}

1 Segundo esta mesma fonte, a Região de Ribeirão Preto, que engloba 25 cidades, possui 384.758 hectares plantados em cana e cerca de 40 usinas que produzem $30 \%$ do álcool e do açúcar do país.

2 Segundo dados fornecidos pelo NERA (Núcleo de Estudos e Projetos de reforma Agrária), da UNESP, CPT (Comissão Pastoral da Terra), e MST (Movimento dos Trabalhadores Rurais Sem Terra), publicados pela Folha de S. Paulo (12/09/04, p. B 8), o desemprego no campo gerado pela mecanização assim se apresenta: na cultura do algodão, são abolidos 60 empregos para cada vaga aberta pela mecanização; nas culturas do feijão e da cana, este número é 400. Isto significa que a mecanização destas culturas caminha lado a lado com o fechamento das oportunidades de emprego no campo. Considerando seis importantes cidades da região de Ribeirão Preto Araraquara, S. Carlos, Franca, Barretos, Sertãozinho e Ribeirão Preto, em 2002, havia 6624 vagas para o setor da agropecuária; em 2003, este número caiu para 3626, o que 
corresponde a uma queda de mais de mil empregos suprimidos naquele setor. (Folha de S. Paulo, 26/08/04, Folha Ribeirão, C3).

Todavia, ao lado do desemprego provocado pela modernização, os incentivos científicos aumentam cada vez mais. Assim, está sendo implantado no IEA de São Carlos, a Rede de Inovação e Prospecção Tecnológica para o Agronegócio (Ripa), cujos objetivos são o desenvolvimento de pesquisas que integrem as diferentes regiões do país. Participam deste projeto de inovação tecnológica, A Embrapa, o Instituto de Tecnologias de Alimentos (Ital), A Associação Brasileira de Agronegócios (Abag) e a Empresa Listen Local Information System. A Ripa tem financiamento no valor de R\$ 1,2 milhão para dois anos proveniente do Fundo Setorial do Agronegócio do MCT ( Informativo IEA (Instituto de Estudos Avançados da Universidade de São Paulo), ano XV, n. 76, out. nov. 2004, p.3).

${ }^{3}$ Segundo as palavras do empresário, Murilo Biaggi Filho,a vitória do Brasil na OMC (Organização Mundial do Comércio), o setor sucroalcooleiro vive seu momento de apogeu, algo constatado na $12^{\mathrm{a}}$ Fenasucro (Feira nacional do setor sucroalcooleiro), cujos negócios movimentados superaram a casa dos R $\$ 500$ milhões. (Folha de S. Paulo, 05/09/04, Caderno G 2).

O Brasil obteve uma grande vitória sobre a União Européia na OMC (Organização Mundial do Comércio) na questão do açúcar. Segundo o governo, a organização considerou ilegais, em parecer preliminar, os subsídios europeus à produção. Esses subsídios, segundo Itamaraty, geram um prejuízo de U\$\$400 milhões por ano aos produtores brasileiros. No processo do açúcar, o Brasil e seus aliados argumentam que a U E não cumpriu os compromissos de redução de subsídios à exportação assumidos com a OMC.

" [ Os subsídios] levaram a Europa exportar açúcar em quantidades maiores do que a que está permitida no acordo da OMC", afirmou o subsecretário - geral de Assuntos Econômicos e Tecnológicos, Clodoaldo Hungueney. No acordo Agrícola da OMC, os países que subsidiam produtos têm um limite anual de exportações. As queixas brasileiras se concentram em dois pontos fundamentais: a produção de açúcar subsidiado na Europa em volumes superiores ao consumo interno e a reexportação subsidiada de açúcar comprado dentro do sistema de preferências tarifárias que U E oferece a alguns países da África, do Caribe e do Pacífico e, em menor escala, a Índia. (Folha de S. Paulo, Folha Dinheiro, 25 de agosto de 2004, p.3 
4 Seis dos oito suspeitos de envolvimento no assassinato dos três ficais e do motorista Ministério do Trabalho, em Unaí ( MG), foram transferidos ontem de Brasília para Belo Horizonte, onde ficarão presos. Entre os suspeitos transferidos para a capital mineira, está o empresário Noberto Mânica, acusado de ser o mandante dos crimes. Após serem apresentados ao Juiz, Franscisco de Assis Betti, da $9^{\text {a }}$ Vara Federal em Belo Horizonte, todos foram levados para a penitenciária estadual, Nelson Hungria, em Contagem (região metropolitana de Belo Horizonte), onde ocuparão celas individuais, em uma ala destinada a presos federais. (Folha de S. Paulo, 21 de agosto de 2004, p.A10).

5 Observatório Social, N. 6, junho de 2004. Graças à reportagem sobre os trabalhadores escravizados na produção de carvão na Amazônia, destinada à grandes empresas siderúrgicas do país, logrou-se um resultado bastante promissor. As principais siderúrgicas que atuam na região norte assinaram uma carta-compromisso pela qual, sanções comerciais serão impostas a empresas que empregam o trabalho escravo na cadeia produtiva do ferro gusa, exportado para vários países. (Primeira Página, São Carlos, C6, 14 de agosto de 2004).

6 Folha de S. Paulo, 19 de julho de 2004, A8).

7 Folha de S. Paulo, 18 de julho de 2004, A4).

8 Folha de S. Paulo, 13 de agosto de 2004, A10).

9 Folha de S. Paulo, 9 de setembro de 2004, A10.

10 Folha de S. Paulo, 18 de julho de 2004, A7.

11 Folha de S. Paulo, 17 de junho de 2004, C3.

12 Folha de S. Paulo, 24 de julho de 2004, A5.

13 Todas estas informações foram selecionadas e coligidas por Jadir Ribeiro, agente da Pastoral dos Migrantes de Guariba, sob o título, Escravidão Sutil.

14 POSADAS, 2002.

5 Pastoral dos Migrantes/Guariba. Rota da Mobilidade Humana para o interior paulista. Dossiê 2001-2003.

16 SILVA,1999.

17 APARICIO, 2002.

18 APARICIO, op. cit.

19 Em 2001, durante uma pesquisa num Assentamento, próximo à Araraquara, uma jovem viúva discorreu sobre a morte do marido de apenas 22 anos de idade, após ter cortado 10 toneladas de cana. Acometido por fortes dores no peito e cãibras, faleceu 
naquele mesmo dia. Segundo a depoente, outros casos haviam ocorrido. Em todos eles, os laudos médicos atestavam enfarte.

20 As usinas em Rio Brilhante, no estado de Mato Grosso do Sul foram alvo de muitas denúncias de trabalho escravo e assassinatos de trabalhadores por capangas. (ESTERCI, 1994, p.64; MARTINS, 1995, p.13; MARTINS, 1999, p.130).

21 No tocante ao Vale do Jequitinhonha, a maioria das mulheres não migra para o corte da cana. No entanto, há migração de mulheres para a colheita do café. Muitas delas estão acompanhadas de filhos pequenos. (SILVA, 1988). A pesquisa citada de Esterci mostra que as mulheres que fazem parte da rede de peonagem estão em cabarés ou realizam trabalhos domésticos como cozinhar e lavar roupas para os peões nos locais de trabalho ( 104-126)

22 MARTINS, 2004. Agradeço ao autor, o envio do artigo por e-mail, no dia 24/05/2004).

23 SEN, 2000.

24 Sobre a fuga como medo, ver a interessante reflexão de DEJOURS, C. $A$ banalização da injustiça social. $2^{\mathrm{a}}$. edição. Rio de janeiro: FGV, 1999, p.82 e ss.

26 No ano de 2004, a Pastoral dos Migrantes registrou tr es mortes nos canaviais desta região. Neste ano de 2005, foram registradas duas mortes no município de Guariba, segundo o relatório da Pastoral dos Migrantes:

"Dois trabalhadores migrantes que moravam temporariamente em Guariba (SP) morreram após rotina pesada no corte da cana. Em julho deste ano, o cortador de cana apelidado como "Pipiu", 26 anos, cortava cana, fustigado pelo sol forte em Guariba, quando, por volta das 14 horas, desmaiou. Foi levado às pressas para o hospital das clinicas, em Ribeirão Preto (HC-RP). Poucas horas depois, ele morria, deixando mulher e filhos em Codô, Maranhão. Seu corpo foi levado para sua família, em Codô.

"Pipiu" havia chegado à região de Guariba em março deste ano e estava cortando cana para o Engenho Moreno de Luiz Antônio (SP). Mas seu colega de trabalho, Alexandre do Nascimento Jance afirma que ele "Pipiu" já foi encaminhado ao hospital morto.

O outro trabalhador que também morava em Guariba, Alcides de 24 anos, morreu após passar mal logo pela manhã, assim que começou trabalhar cortando cana, também no Engenho Moreno. 
Segundo o Ivanilson que trabalhava com Alcides ao desmaiar, ele caio. Ele recebeu os primeiros socorros na hora, e depois foi levado a um hospital, onde foi declarado morto.

Parentes e amigos dos dois mortos que estavam com eles nas pensões de Guariba afirmaram que eles não tinham problemas de saúde que eles conheciam. Os nomes completos deles não foram divulgados.

Essa não foi a primeira vez em que trabalhadores migrantes morrem no pé do eito cortando cana no interior paulista. Em abril do ano passado, três trabalhadores em regiões diferentes morreram, enquanto estavam cortando cana, testando os limites físicos na busca de lucros. Um deles, Manoel Pinto Neto, 34 anos, morreu em Palmares Paulista, quando abraçava a cana para desferir o golpe de facão. Seu túmulo está em estado de abandono, no cemitério de Palmares. Segundo os boletins das ocorrências, ambos os trabalhadores morreram de paradas respiratórias.

A Pastoral do Migrante desconhece os casos das mortes, mas supostamente foram provocadas pelo excesso de trabalho, o que os cortadores de cana chamam de "birola". (Colaboração, Jadir Ribeiro Pela Equipe da Pastoral).

27ELIAS, 1990, p. 194. 


\section{BIBLIOGRAFIA}

ANDRADE, A . F. Cana e crack: Sintoma ou problema? Um estudo sobre os trabalhadores no corte de cana e consumo do crack. Dissertação de Mestrado. PPG/Psicologia Social/PUC/SP, 2003.

APARICIO, S. et al. Una nueva intermediación en los mercados de trabajadores. VI Congresso Alasru 25-19 de novembro de 2002 Porto Alegre UFRGS.

ELIAS, N. O Processo civilizacional. 2º . v. Lisboa: Dom Quixote, 1990, p. 194.

ESTERCI, N. Escravos da desigualdade.Um estudo sobre o uso repressivo da força de trabalho hoje. Rio de Janeiro: CEDI, Koinonia, 1994.

ESTERCI, N. A dívida que escraviza. In: Trabalho escravo no Brasil contemporâneo. São Paulo: Loyola, 1999, p. 101-126.

FEDMAN-BIANCO, B; HUSE, D. Entre a saudade da erra e a América: memória cultural, trajetória de vida e (re) construções de identidade feminina na intersecção de culturas. In: Brandão, C. R. (org.) As faces da memória. Coleção Seminários, 2, CMU/UNICAMP, sd.

FIGUEIRA, R. R. Condenados à escravidão. In: Trabalho escravo no Brasil contemporâneo. São Paulo: Loyola, 1999, p. 165-208.

MARTINS, J. S. A escravidão nos dias de hoje e as ciladas da interpretação. In: Trabalho escravo no Brasil contemporâneo. São Paulo: Loyola, 1999, p. 127-164.

MARTINS, J. S. A reprodução do capital na frente pioneira e o renascimento da escravidão no Brasil. Tempo Social, N. 6, V. 1-2, 1994, p. 1-25.

MARTINS, J.S. A nova face da escravidão. Família Cristã. Ano 70, N. 821, maio de 2004, p. 64-65.

MOORE Jr., B. Injustiça. As bases sociais da obediência e da revolta. São Paulo: Brasiliense, 1987.

POSADAS, F. et. al. Estructura social y trabajadores agrícolas en el Noroeste de México. VI Congresso Alasru 25-19 de novembro de 2002, Porto alegre UFRGS.

NOVAES, J. R. Uma iniciativa louvável. O Encontro dos trabalhadores migrantes do Piauí. Boletim das Migrações, Vaivém, Ano 23, N. 96, jul/set de 2004, p. 4-5.

RUMIN, C. Trabalho rural e saúde: um estudo das condições de trabalho e sua relação com a saúde dos cortadores de cana no município de Pacaembu/SP. Dissertação de Mestrado. PPG/Medicina Social/USP/Ribeirão Preto, 2004.

SEN, A. Desenvolvimento como liberdade. São Paulo: Companhia das Letras, 2000. 
SILVA, M. A. M. A migração de mulheres do Vale do Jequitinhonha para São Paulo: de camponesas a proletárias. Travessia, Ano 1, V. 1, 1988, p. 9-15.

SILVA, M. A. M. A terra no imaginário dos camponeses migrantes. História Oral, N. 4, junho de 2001, p.103-120.

SILVA, M. A. M. Errantes do fim do século. São Paulo: Edunesp, 1999.

SILVA, M. A. M. Se eu pudesse, eu quebraria todas as máquinas. In: ANTUNES, R.; SILVA, M. A. M. (ORG.). O avesso do trabalho. São Paulo: Expressão Popular, 2004, p. 29-78.

SUTTON, A. Trabalho escravo: um elo na cadeia da modernização no Brasil de hoje. São Paulo: Loyola, Anti-Slavery International, 1994.

THOMPSON, E, P. A formação da classe operária inglesa. V. 2, Rio de Janeiro: Paz e Terra, 1987, p. 64. 